\title{
Intensification of Arable Agricultural Land Use As A Response To Changing Agro-Ecological Context In The Benue Basin, Nigeria
}

\author{
Daniel S. Ortserga \\ Department of Geography, Benue State University, Makurdi
}

Felix K. Kwaghsende

Department of Urban and Regional Planning, Benue State University, Makurdi

Daniel P. Dam

Department of Geography, Benue State University, Makurdi

Tracy I. Kile

Department of Geography, Benue State University, Makurdi

\author{
Fanan Ujoh \\ Department of Urban and Regional Planning, Benue State University, Makurdi \\ Timothy T. Gyuse \\ Department of Urban and Regional Planning, Benue State University, Makurdi
}

\begin{abstract}
This study investigated intensification of rural agricultural land use as a response to the changing agro-ecological context in the Benue basin. The objectives were to describe the changing agro-ecology of the region that is stimulating this response from farmers and to assess the level of agricultural land use intensification in the area. Field survey was the main design for data collection and was supplemented by archival search to access knowledge on the process of state intervention in the agricultural systems, population and settlement change in the area. A sample of 1,500 farming households, shared uniformly among the five states covered by the study, was used and questionnaire was the major instrument for data collection. In addition, the study made field observations and took photographs to depict farm scenes. Results showed that agro-ecological circumstances in the region have altered as manifested in over $100 \%$ rise in average population densities since 1991 in all the five states investigated as well as rapid urban expansion. It was also found that access to new farming technologies in form of new crop varieties, fertilisers and other farm chemicals has improved for $\mathbf{7 8 \%}$ of respondents in the area through activities of government agencies such as agricultural institutions, agricultural development projects and river basin development authorities, and large scale farms which have emerged in the region. Also significant is the finding that farmers in the basin have accepted the philosophy and principles of productivist agriculture which commoditise production for the market. They are therefore prepared to accept the limited innovations that are available. The study recommends deliberate policy to exploit farmers' disposition towards innovation adoption and commercialisation of production in the area through improved access to new farm technologies and extension services.
\end{abstract}

Key words: Changing agro-ecology, response, intensification, agricultural development. 


\section{INTRODUCTION}

The continued survival of any agricultural system depends on its capability to adjust to the evolving dynamics of agro-ecological environment of an area. If appropriate adjustments are not made, a farming system either declines in production or is ruined altogether. Usually the sustainability of agriculture manifests in successive levels of land use intensity which adapts to new environmental factors of soils, rainfall regime and weed invasion (Moss, 1969); social factors of labour, population growth, relations of production and land tenure arrangement (Stone, 2001); economic factors of transport and market (Freeman, 1984); and availability of alternative employment and income among farming households (Kodithuwakku and Rosa, 2002); access to new crop varieties and market demand.

Farming space is by and large inelastic just like space for any other land use is in an ecumene world. Nevertheless, increase in population and consumption levels which agriculture must support keep changing over time to necessitate increase in agricultural production. The need to match agricultural production with fast growing demand can only be met in a sustainable manner through intensification of use of available arable land. This axiom holds true both at global, regional, national and local scale.

Generally, two paths of intensification of agricultural land use are available for choice: the agro-ecological and industrial paths. Agro-ecological path involves such practices as interplanting, intercropping, plant-livestock integration, agroforestry and increased frequency of land use (Kwa, 2001). The industrial path involves application of chemical inputs, machinery and improved varieties of crops. Agro-ecological path, otherwise known as non-industrial approach does not sustain high input-output ratios in the long run as the output ratios decline with increasing frequency of land use. However, output ratios rise with increased capital investment in the case of industrial intensification of land use (Freeman, 1994; Stone, 2001). This affords greater sustainability of agricultural land use in an area. The only problem with industrial methods of farming is that they are not environment friendly as some of the chemicals used are not easily degradable (Fold and Tacoli 2010). Owing to social appropriateness and lower cost, agro-ecological approach is usually common among smallholder farmers, especially in developing countries.

Since the second half of the $20^{\text {th }}$ century, the challenge of crop supply has largely been met mainly by industrial intensification of agricultural land use. Pellegrini and Fernandez (2018) report that between 1961 and 2014 world crop production increased by threefold, coming mainly from 58 countries that were responsible for $95 \%$ of global production. Using increased application of machinery, fuel and fertiliser per hectare as a measure of agricultural intensification, they attribute the threefold increase mainly to the use of these physical inputs which increased during the period by $137 \%$ while cultivated acreage expanded by just $10 \%$. The only shortcoming of industrial methods of intensifying farming land use is that they pollute the environment and the crops they support in the long term. In the past, discussion on agricultural land use intensification was concerned essentially with what Dornbush and von Haden (2017) call 'yield delivery' while overlooking its negative effects. At present however, the call for ecological intensification (Bammarco, et al, in Dornbush \& van Haden, 2017) which protects ecosystem services is becoming loud.

Though not practised at the scale seen in advanced countries, developing countries generally and Nigeria especially, mixes both agro-ecological and industrial methods of intensification of agricultural land use. Prior to general monetisation of economies in Nigeria, traditional communities used to adjust to new dynamics of agro-environment mainly by non-industrial intensification. They could augment that approach with out-migration where conditions 
permitted. At present, no community responds to changes in ecological and socio-demographic conditions solely by non-industrial intensification approach. Even the most underdeveloped community may still have some form of access to one type of new technology or another and makes capital investment in its farming enterprises in a bid to intensify use of farmland.

The physical environmental system in the Benue basin, comprising soils, vegetation, animal component along with the social and political aspects of man-environment relationships have altered over time to necessitate change in the way land is used for agricultural production. This change manifests in shifting levels of intensification of land use through both industrial and non-industrial approaches. This work set out to investigate the current link between these shifts in levels of land use intensity and the context in which they are happening. The specific objectives were:

i. To describe agro-ecological setting that provides the context for land use intensification in the Benue basin;

ii. To assess the level of agricultural land use intensification in the Benue basin;

\section{THEORETICAL OVERVIEW}

Literature abounds with models of agricultural land use change from low intensity to high intensity as a way of adjusting to evolving social, economic, technological and ecological circumstances of an area. The entire socio-physical environment within which farming takes place is highly dynamic, being subject to endless exogenous and endogenous influences. Classical notion of intensification of agricultural land use as held by Ricardo and Thunen (cited in Grigg, 1979) which remains valid to date, refers to a deliberate effort by a farmer to realise higher farm yield per unit area through increased application of capital and labour. It is a process of heightened land use activity on a plot of land (Scarborough, 2012) as a response to contextual shift in an agricultural region.

One model that explains this response is the ecological theory of land use change by Moss (1969) which posits that alterations in components of the environment usually makes introduction of changes in agricultural land use unavoidable. The environmental system is seen as comprising soil, vegetation and animal components, which are all relevant variables in land use shift. Soil properties such as nutrient status, organic matter and activities of microorganisms are subject to change under continued cultivation. Vegetation and animal components provide cover to soil and act as nutrient reservoir for the soil. The theory maintains that agricultural land use in any area relies on the delicate balance between the agronomically useful components of the environment. When these components deplete in a manner that creates imbalance or total deficiency, crop yield begins to decline, requiring increased investment in capital and labour inputs to invigorate the soil to continue to yield. According to Ortserga (2010), the intensity of capital and labour input application depends on the extent of degradation of the environmental components in an area.

Agricultural land use intensification in the Benue basin can be contextualised in the changing ecological circumstances of the region. All components of the basin's ecology have evolved over time. Population has grown within an inelastic terrestrial space to give rise to increasing densities. Associated with population growth has been settlement evolution in form of increased urbanisation in the last 100 years. In addition to these developments has been the integration of the region's economy with the national and international economies which opens access to widening produce market and new farming technologies in form of machinery, chemicals and new crop varieties. It is in response to shifts in the micro and macro environments that farmers in the region are intensifying agricultural land use. 


\section{The area}

\section{MATERIALS AND METHOD}

The Benue basin is an area drained by River Benue and its tributaries as a single drainage system in the eastern part of central Nigeria. It spans from latitudes $6^{\circ} 13^{\prime}, 10^{\circ} 54^{\prime} \mathrm{N}$ and $5^{\circ} 13^{\prime}$, $13^{\circ} 42^{\prime} \mathrm{E}$; covering the States of Kogi, Benue, Nasarawa, Taraba and Adamawa as shown in Figure 1. The area is suitable for a wide range of agricultural productions as it receives rich alluvial deposits annually during flood period along the plains of the numerous tributaries and along the plains of the Benue River itself. Climate is typically tropical continental with marked wet and dry seasons. Owing to its ecologically balanced location between the forest and savannah biomes, virtually all tropical crops, ranging from tubers to cereals and fruits can be grown profitably in the region. The area has been home to a long standing culture of indigenous agriculture.

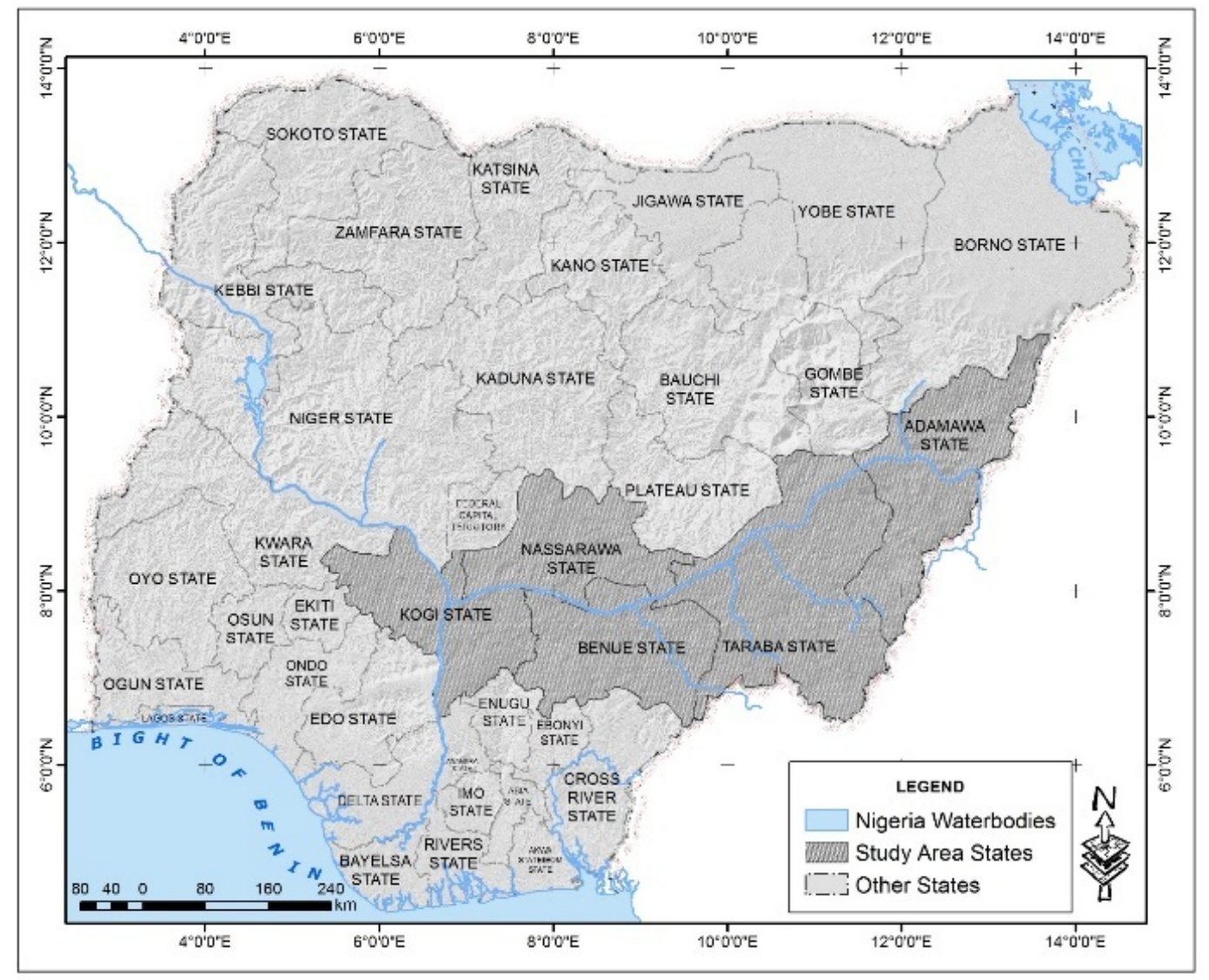

Figure 1: Map of Nigeria showing the study area

\section{Design for fieldwork}

The study employed field survey as the main strategy for data collection. This was deemed apt because much about change in agricultural land use systems involves decision making at the level of individual farming households. The reasons for deciding which crops to plant and which methods of intensification to employ are best known to individual farmers. Information regarding these aspects can only be accessed through questionnaire administration. In addition, search for secondary information regarding history of intervention in the agricultural systems, population and settlement change in the region was undertaken to obtain an insight into the origin of intensification process in the area. Keen observations of farmlands were also made, and some scenes of farming activity were captured in photographs. 


\section{The population of the study}

The target population for the study comprised farming households in the Benue basin. Specific contacts for field interaction were heads of households who normally take decisions regarding types of crops to cultivate, kinds of inputs to use and when and where to sell farm produce. Other elements of the population included farm plots, regarded as specific sites of land use activities. The size of this population was not known owing to lack of previous baseline studies and farm level surveys for the area.

\section{Sample size and sampling procedure}

A sample of 1,500 rural farming households was used, and each of the five states was allotted a sub-sample of 300 households. The uniform allotment of 300 sample units per state was not based on the base population of farmers in the states. The reason for not applying the principle of proportionality in deciding sample size and its allotment among the states was because no previous authentic data on farming households was available, and it was beyond the scope of the study to conduct a census of farmers in the area so that the principle could be applied. Uniform distribution of sample among the states was also deemed appropriate because communities in the states were considered to be agriculturally homogeneous, producing virtually identical crops and using more or less same methods and similar inputs on farms. The distribution of sample among the five states and rate of retrieval of copies of questionnaire are shown in Table 1.

Table 1: Allotment of samples among the states covered in the study

\begin{tabular}{lcc}
\hline State & $\begin{array}{l}\text { Rural sample } \\
\text { distributed }\end{array}$ & $\begin{array}{l}\text { Rural sample returned in a } \\
\text { form that could be } \\
\text { analysed }\end{array}$ \\
\hline Adamawa & 300 & 299 \\
Benue & 300 & 295 \\
Kogi & 300 & 159 \\
Nasarawa & 300 & 298 \\
Taraba & 300 & 250 \\
\hline Total & 1500 & 1301 \\
\hline Source: Fieldwork, 2017 &
\end{tabular}

Five farm sites were chosen for close observation of production contents, field practices and labour used. They were Sebore Farms in Adamawa State, Ortom Farms in Benue State, vegetable farm at Buruku in Benue State, Olam Farm in Nasarawa State and dry season farm in Lokoja (Kogi State). Sebore Farms and Olam Farm were large modern farms employing industrial methods; Ortom Farm was large scale enterprise that mixed industrial and agroecological methods of intensification while the vegetable farm at Buruku and the Lokoja farm were small scale farm plots using agro-ecological methods.

\section{Data collection procedure}

Data for the study was obtained through questionnaire administration. This was achieved by face to face administration of the field document by field assistants who were given adequate rehearsal for the field exercise. The method afforded the assistants opportunity to explain issues to respondents so that they understood the document for more reliable responses. In each state, a local government area was randomly selected for field investigation and a farming community was chosen for questionnaire administration. In the course of the field activity, farm plots were observed to confirm responses. In some cases, farmers were seen harvesting crops, thereby confirming responses given regarding types of crops, farm tools and labour used. Photographs of farm plots were also taken, especially for farms that were under crops 
and mechanical harvesting. Information about ecological setting was obtained from published works and archival materials were consulted to get information on history of intervention in agricultural land use of the basin.

\section{Data analysis}

Data were presented in tables and analysed using graphs and pie charts. Tables combined raw information on variables with their percentage values. In this way, relative frequencies of items and their percentage values among the five states covered by the study were revealed for comparison.

\section{RESULTS AND DISCUSSION}

The process of intensification of agricultural land use in the Benue basin is not new. It started with agro-ecological methods of intercropping, crop substitution, crop rotation and plantlivestock integration; and transited to quasi-industrial approaches seen at present. For the extent of the process to be appreciated, the origin of intensification of agricultural land use in the Benue basin was investigated from published works.

\section{Historical overview of agricultural land use in the Benue basin}

It could be argued that some levels of agricultural land use intensification existed in the Benue basin long before the intervention into the farming systems of the region by the colonial state. Communities in the region had substituted one variety of crop for another and interplanted several crops on one plot. These were measures they employed to increase yield per unit land, especially in areas of land shortage where, as Okafor (1982) noted, population could not spread out due to security concern.

Formal intervention by the colonial state which introduced quasi-industrial approach to intensification of agricultural land use began in 1912 when colonial authority established a Department of Agriculture in northern Nigeria which produced new crop varieties and disseminated same to native farmers (Forrest, 1986). Intensification of land use by substituting new and better yielding crop varieties for traditional varieties however involved mainly export crops, citrus and yam. At present, citrus and mango orchards within the basin are mainly located in parts of the basin where government influence was most intensely felt such as eastern Benue State, southern Nasarawa and central part of Adamawa State.

According to Forrest (1986), more widespread limited industrial methods of intensification were introduced in the region in the 1970s and were part of post-colonial period policy correction by government in favour of food crop production. With the policy shift, subsidies were granted on credits and farm inputs, especially fertilisers. The period also witnessed establishment of two river basin authorities in the Benue basin: the Upper Benue Basin Development Authority with headquarters in Yola, Adamawa State and the Lower Benue Basin Development Authority with headquarters in Makurdi, Benue State. At the same time two World Bank assisted agricultural development projects (ADPs) were established in the region, one in Ayangba, Kogi State and another in Lafia, Nasarawa State. The river basin development authorities and agricultural development projects provided farm services in form of inputs, credits, mechanical implements and extension services (Sule, 2006).

Changes in the intensity of agricultural land use in the Benue basin were all a reaction to increasing ecological stress of the environment in the region, especially occasioned by population growth and its rising rural densities and concentrations in the emerging urban settlements. Rising rural densities created land shortages and raised frequency of plot use in some communities which in turn stressed the soil; and emerging urban centres generated 
domestic demand for virtually all farm produce which spurred farmers to adopt any available technique for greater production. In other words, changes in the region's ecology upset the natural potentials of the agro-environment to support profitable farming enterprise unaided, necessitating further intensification of land use in the area.

\section{The agro-ecological setting of the Benue basin}

Benue basin lies between the forest and savannah zones of Nigeria. It is therefore home to forest and savannah ecosystems, rich in diverse tree and grass species, animals and insects, giving rise to profuse supply of organic materials that constantly enrich the soils. The basin generally has hospitable relief, being characterised by extensive plains in many places such as parts of Benue State, southern Nasarawa State, central and western Taraba State; and undulating surfaces in Kogi and Adamawa States. It is only the north-eastern portion of the basin that shows rugged relief, especially towards the Cameroon border. The climate is of the tropical wet and dry type (the Aw climate, according to Koppen's classification, cited in Strahler \& Strahler, 1994). Rainfall though seasonal, is adequate during wet period for most crops and usually floods the valleys of the numerous rivers of the basin, depositing thick layers of alluvia annually on the surface. The gallery forests fringing river courses were sources from where many local crop species were domesticated before the colonial administration began intervention into the region's agriculture (Personal communication with Tukwa, 2009).

In the course of time however, components of the environment such as soil fertility, forest cover, weeds, crop pests and diseases, and density of human population have changed due to sustained anthropogenic activities, especially arable farming, requiring appropriate adjustments in agricultural practice to the evolving environment.

\section{The demographic shift in the Benue basin}

Intensification of agricultural land use in any area is mainly a function of increasing population densities. Rising population densities necessitate the introduction of intensive techniques of farming to circumvent the problem of land shortage. That is why in regions of land surplus, only few people think of intensifying use of land because intensive land use requires more efforts to achieve production.

One of the fundamental drivers of agricultural land use intensification in the Benue basin has been increase in population densities in rural areas, and growing concentrations in urban centres of the region. Increasing rural population supplies labour on farms needed to satisfy higher labour requirement of emerging intensive farming system. The growing urban population in the basin which has come in the wake of population growth provides demand for virtually all farm produce, thereby creating continuous incentive for intensification of agricultural land use.

Changes in the density of population in the Benue basin can be appreciated from the evolving density scenario between 1991 and 2017 for which actual census records and projected figures are available. During the period average densities in the five states of the basin grew by more than $100 \%$ as shown in Table 2 . 
Table 2: Rising population densities in the Benue basin between 1991 and 2017

\begin{tabular}{llllllll}
\hline State & Area & \multicolumn{2}{c}{1991} & \multicolumn{2}{c}{2006} & \multicolumn{2}{c}{2017} \\
\cline { 3 - 8 } & $\left(\mathrm{km}^{2}\right)$ & Popn & Density & Popn & Density & Popn & Density \\
\hline Adamawa & 35,470 & $2,102,053$ & $59 / \mathrm{km}^{2}$ & $3,168,101$ & $89 / \mathrm{km}^{2}$ & $4,338,786$ & $122 / \mathrm{km}^{2}$ \\
Benue & 32,910 & $2,753,077$ & $84 / \mathrm{km}^{2}$ & $4,219,244$ & $128 / \mathrm{km}^{2}$ & $5,840,420$ & $177 / \mathrm{km}^{2}$ \\
Kogi & 32,440 & $2,147,756$ & $66 / \mathrm{km}^{2}$ & $3,278,487$ & $101 / \mathrm{km}^{2}$ & $4,538,193$ & $140 / \mathrm{km}^{2}$ \\
Nasarawa & 26,876 & - & - & $1,863,275$ & $69 / \mathrm{km}^{2}$ & $2,579,208$ & $96 / \mathrm{km}^{2}$ \\
Taraba & 55,920 & $1,512,163$ & $27 / \mathrm{km}^{2}$ & $2,300,736$ & $41 / \mathrm{km}^{2}$ & $3,150,908$ & $56 / \mathrm{km}^{2}$
\end{tabular}

Source: Adapted from National Population Commission (1998); Fed. Rep of Nigeria, Official Gazette (2007) and Ayih (2003).

Owing to the combined effect of rising rural densities and increasing urbanisation in the region, the area of agricultural land in many communities has reduced in the face of mounting demand for almost all farm produce. Farming system in the area has reacted to this development by intensifying use of available land.

The rapid rate of population growth in the basin has also been replicated in high rate of urban expansion in the area which in turn has created large growing population concentrations that offer demand for increased crop production. For example, all the headquarters of the five states covered in the study have experienced rapid rate of urban expansion between 1976 and 2016 as shown in Table 3.

Table 3: Rate of expansion of the five capital cities in the Benue basin, 1976-2016

\begin{tabular}{lllllll}
\hline Capital city & $\begin{array}{l}1976 \\
\text { Area } \\
\left(\mathrm{km}^{2}\right)\end{array}$ & $\begin{array}{l}1986 \\
\text { Area } \\
\left(\mathrm{km}^{2}\right)\end{array}$ & $\begin{array}{l}1996 \\
\text { Area } \\
\left(\mathrm{km}^{2}\right)\end{array}$ & $\begin{array}{l}2006 \\
\text { Area } \\
\left(\mathrm{km}^{2}\right)\end{array}$ & $\begin{array}{l}2016 \\
\text { Area } \\
\left(\mathrm{km}^{2}\right)\end{array}$ & $\begin{array}{l}\text { Average } \\
\text { annual change } \\
\left(\mathrm{km}^{2}\right)\end{array}$ \\
\hline Jalingo & 8.377 & 13.381 & 21.247 & 45.617 & 53.043 & 1.120 \\
Makurdi & 20.920 & 36.248 & 96.912 & 169.213 & 234.741 & 5.350 \\
Lafia & 6.284 & 35.393 & 69.875 & 210.933 & 351.765 & 8.64 \\
Lokoja & 44.678 & 54.880 & 169.970 & 417.044 & 569.970 & 13.13 \\
Yola & 4.215 & 8.901 & 19.606 & 50.224 & 172.079 & 4.200 \\
\hline
\end{tabular}

Source: Iorliam et al (2017)

It should be noted that built up areas form significant proportions of the physical expansion of all the capital cities as shown in Table 3. Since the built up areas actually hold the population, their consistent growth testifies to the increase of people who are off the land and must be sustained by an agriculture which guarantees adequate supply of farm produce. The growth of the five capital cities represents the region-wide population change. Several other lesser concentrations have emerged in the basin and rural densities are rising to justify land use intensification in the area.

\section{Techniques of intensification of agricultural land use in the Benue basin}

Several measures of intensifying agricultural land use involving both agro-ecological and industrial methods are employed by farmers in the Benue basin. The agro-ecological methods in particular, work well in the area due to the diverse natural environmental qualities of the region, being situated between the forest and savannah zones. The combination of approaches to intensification of land use is indicative of an agricultural system in transition. The techniques are discussed in subsequent sections. 


\section{Interplanting}

Intensification of agricultural land use in the Benue basin employs both agro-ecological and industrial techniques to achieve higher total yield per unit land. By agro-ecological approach, farmers plant different crops on the same plot of land at the same time. The common crops grown in this manner are shown in Table 4.

Table 4: Common crops grown on farms in the Benue basin

\begin{tabular}{|c|c|c|c|c|c|c|c|c|}
\hline \multirow{2}{*}{\multicolumn{3}{|c|}{ Main arable crops }} & \multicolumn{5}{|c|}{ State } & \multirow[t]{2}{*}{ Total } \\
\hline & & & Adamawa & Benue & Kogi & Nasarawa & Taraba & \\
\hline \multirow[t]{2}{*}{ Yam } & Count & & 10 & 179 & 30 & 196 & 86 & 501 \\
\hline & $\begin{array}{l}\% \\
\text { sttate }\end{array}$ & within & 3.4 & 61.7 & 16.2 & 76.9 & 36.3 & 39.8 \\
\hline \multirow[t]{2}{*}{ Cassava } & Count & & 53 & 106 & 61 & 18 & 23 & 261 \\
\hline & $\begin{array}{l}\% \\
\text { state }\end{array}$ & within & 18.2 & 36.6 & 33.0 & 7.1 & 9.7 & 20.7 \\
\hline \multirow[t]{2}{*}{ Sorghum } & Count & & 53 & 3 & 5 & 8 & 22 & 91 \\
\hline & $\begin{array}{l}\% \\
\text { state }\end{array}$ & within & 18.2 & 1.0 & 2.7 & 3.1 & 9.3 & 7.2 \\
\hline \multirow[t]{2}{*}{ Rice } & Count & & 146 & 2 & 30 & 22 & 58 & 258 \\
\hline & $\begin{array}{l}\% \\
\text { state }\end{array}$ & within & 50.0 & 0.7 & 16.2 & 8.6 & 24.5 & 20.5 \\
\hline \multirow[t]{2}{*}{ Maize } & Count & & 17 & 0 & 2 & 7 & 27 & 53 \\
\hline & $\begin{array}{l}\% \\
\text { state }\end{array}$ & within & 5.8 & 0.0 & 1.1 & 2.7 & 11.4 & ). 4.2 \\
\hline \multirow[t]{2}{*}{ l.Beans } & ?.Count & & 3.0 & 4.0 & 5.6 & 5.1 & 7.2 & 3.9 \\
\hline & $\begin{array}{l}7 . \% \\
\text { state }\end{array}$ & within & ). 0.0 & 1.0 .0 & 2.3 .2 & 3.0 .4 & t. 0.8 & 5.0 .7 \\
\hline \multirow[t]{2}{*}{ j.Soyabeans } & 7. Count & & 3.0 & 7.0 & ) .0 & 1.0 & 2.3 & 3.3 \\
\hline & $\begin{array}{l}1 . \% \\
\text { state }\end{array}$ & within & $; .0 .0$ & 5.0 .0 & 7.0 .0 & 3.0 .0 & 7.1 .3 & 0.0 .2 \\
\hline \multirow[t]{2}{*}{ L.Groundnut } & 2.Count & & 3.5 & 1.0 & 5.51 & 5.0 & 7.9 & 3.65 \\
\hline & $\begin{array}{l}7 . \% \\
\text { state }\end{array}$ & within & ) .1 .7 & 1.0 .0 & 2.27 .6 & 3.0 .0 & 4.3.8 & 5.5 .2 \\
\hline \multirow[t]{2}{*}{ 5.Sugarcane } & 7. Count & & 3.0 & 7.0 & ) .0 & l. 1 & 2.0 & 3.1 \\
\hline & $\begin{array}{l}1 . \% \\
\text { state }\end{array}$ & within & $; .0 .0$ & 5.0 .0 & 7.0 .0 & 3.0 .4 & 7. 0.0 & ). 0.1 \\
\hline \multirow[t]{2}{*}{ l.Others } & 2.Count & & 3.8 & 1.0 & 5.0 & 5.2 & 7.7 & 3.17 \\
\hline & $\begin{array}{l}7 . \% \\
\text { state }\end{array}$ & within & 0.2 .7 & 1.0 .0 & 2.0 .0 & 3.0 .8 & t.3.0 & j.1.4 \\
\hline \multirow[t]{2}{*}{ 5.Total } & 7.Count & & 3.292 & 7.290 & 0.185 & 1.255 & 2.237 & 3.1259 \\
\hline & $\begin{array}{l}1 . \% \\
\text { state }\end{array}$ & within & $\$ .100 .0$ & 5.100 .0 & 7.100 .0 & 3.100 .0 & 7. 100.0 & ). 100.0 \\
\hline
\end{tabular}

Source: Fieldwork, 2017

With several years of practical experience, they know crops that require different nutrients from the same soil and can therefore grow together in one place. Field investigation revealed that farmers in the region grow a wide range of crops in different combinations on same plots of farm land.

Apart from rice and sugar cane which are grown as sole crops, no other crop grows alone on a farm plot in the region. For example, yam is usually interplanted with maize, bean, pepper, okra and other vegetables. Sorghum grows with soyabean which, according to farmers, serves to eliminate the notorious red-flowered root parasite (striga senegalensis) and allows sorghum to yield. Other combinations consist of sorghum and groundnut, cassava and yam, beans and maize. Interplanting is a typical agro-ecological practice in land use intensification which ensures against total crop failure on a farm plot. If one crop fails, another succeeds; and if all the crops succeed, the farmer realises higher yield from a single plot. 


\section{Application of farm inputs}

Use of material inputs to invigorate the soil for higher yield is one of the most conspicuous evidence of intensification of farming land use. At present, there is a growing trend towards use of factory produced materials (both organic and chemical) to enhance the capacity of farm lands for higher productivity. Deliberate use of farm inputs has been a widespread practice among farmers in the Benue basin. Indeed the acceptance of various kinds of inputs by farmers in the area is one proof that they are amenable to agricultural innovations whenever they are properly disseminated. Field responses revealed that industrial inputs such as chemical fertilisers, insecticides and herbicides were in common use at the time of study. Similarly, household manures such as ashes, peels and animal droppings are used on certain crops, especially vegetable crops for the same purpose of raising and sustaining farm yield in the region. Throughout field investigation, no farmer reported leaving crops to natural fertility. Figure 4 shows the prevailing inputs applied to achieve land use intensity on farms.

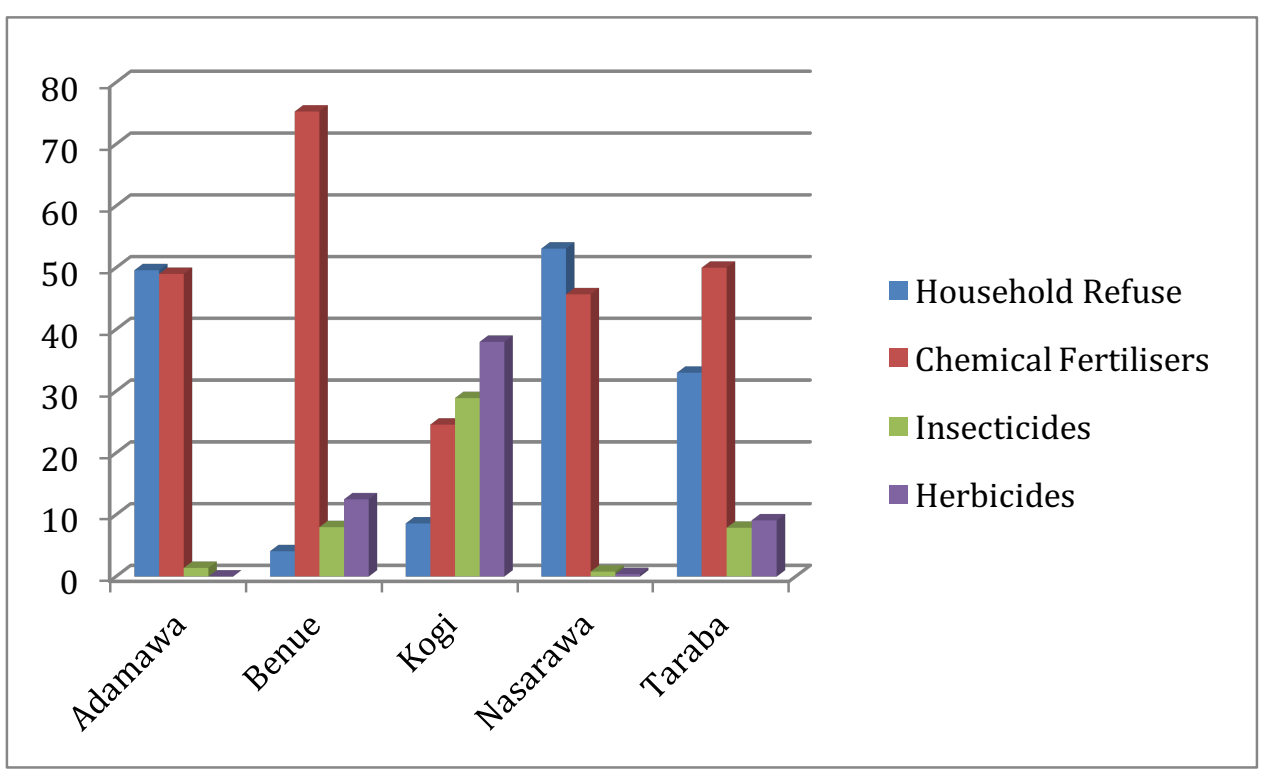

Figure 4: Inputs application in rural agriculture in the Benue basin Source: Fieldwork, 2017

The use of chemical fertilisers, insecticides and herbicides, all factory produced inputs, were reported by $67 \%$ of respondent farmers, chemical fertilisers being the most preferred, while $33 \%$ of respondents reported use of household wastes on their farms. The application of both chemical and organic materials on farms was reported by respondents in the study as means of raising the productivity of the farm lands. In this regard, it is no surprise that the pattern of adoption of input innovations conforms to the geographical pattern of population density and related duration of fallow in the region. Benue State where due to shortage of virgin land has reduced fallow period, shows the highest number of respondents reporting use of chemical fertilisers to sustain productivity of farm lands. With the increasing concern about environmental health and human safety, farmers in the area need to be encouraged to turn more to use of organic inputs.

\section{Varieties of crops grown in the area}

The effort to realise greater yield per unit land sometimes takes the form of substitution of traditional varieties of crops with improved varieties which yield better. It is an industrial method of agricultural land use intensification which involves a wide range of agro-genetic manipulations, from simple grafting of two varieties to produce an improved type to genetic modification of crops. Shift from traditional varieties of crops to improved varieties depends 
on the degree of accessibility of farmers to results of continuous research and enlightenment of farmers in an area. This shift is beginning to manifest in the Benue basin as shown in Figure 5.

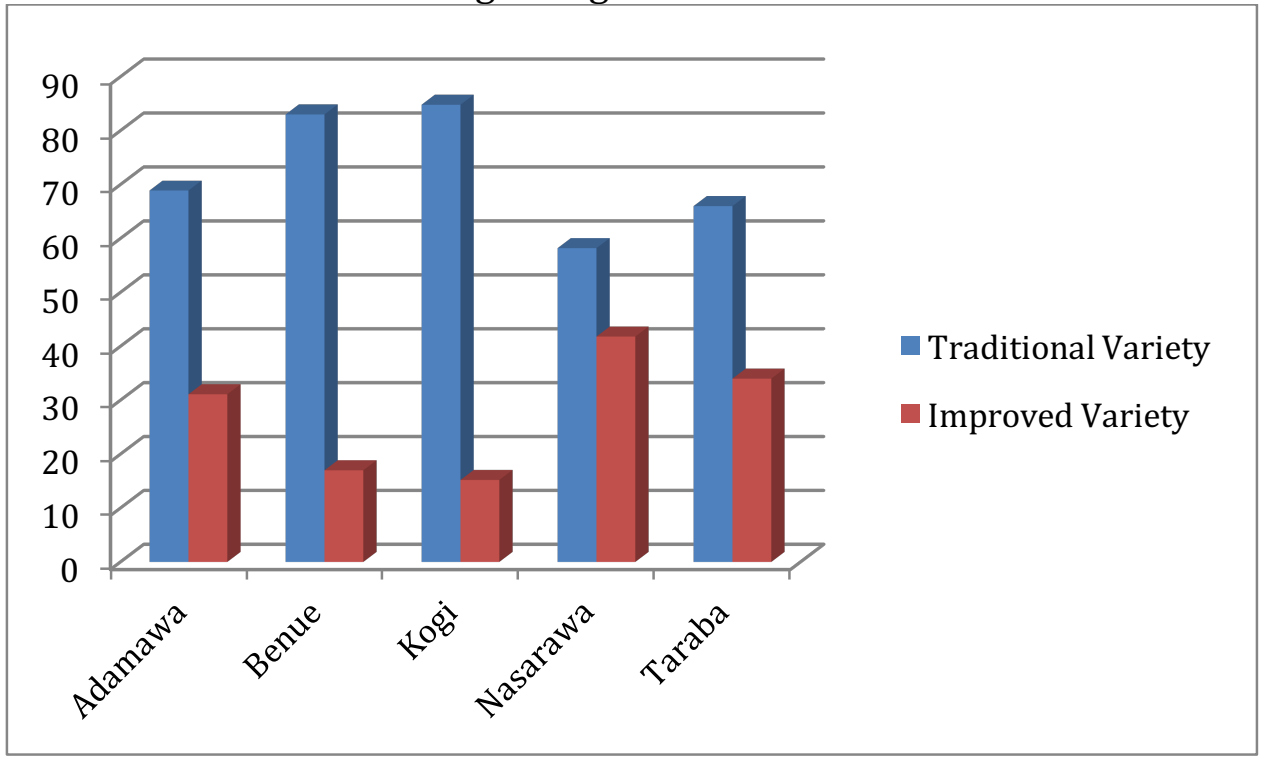

Figure 5: Varieties of crops produced in the Benue basin Source: Fieldwork, 2017

Institutions which created platforms for the shift were Agricultural Experimental Centre at Yandev in present Benue State, Agricultural Development Projects (ADPs) at Lafia and Ayangba in present Nasarawa and Kogi States respectively, Upper Benue Basin Development Authority Yola, Lower Benue Basin Development Authority, Makurdi and the respective state owned agricultural agencies. Change in this regard has been slow, but it is becoming visible.

Nasarawa State shows the highest shift from traditional varieties of crops to improved varieties while Kogi State shows the least adoption rate. Variation in adoption rate is explained by cultural values farmers attach to certain traditional varieties of crops which, as some respondents claimed, taste better than improved varieties.

\section{Frequency of cultivation}

Intensification of agricultural land use is most visibly demonstrated on a landscape by how often farm plots are cultivated. In other words, agricultural land use intensity in an area manifests, among other things, in the length of period plots are allowed to rest before they are used again. The higher the frequency of cultivation, the higher the intensity of land use in an area as the overall yield realised rises with increasing frequency of use. Shift in this form of intensification is a function of increasing density of population which lowers land-population ratio and subject the available land to higher rate of cultivation.

Owing to population growth in the Benue basin in the wake of peace and general improvement in sanitation and health services, rural population densities have risen in the area and have forced duration of fallow to shorten progressively. Findings by the study have shown that majority $(79.5 \%)$ of farmers in the region who were investigated allow only fallow periods of two years and below, $93.5 \%$ of the respondents permit fallow duration of only four years and below. Table 5 shows these findings. 
Table 5: Prevailing fallow periods in rural areas of the Benue basin

\begin{tabular}{|c|c|c|c|c|c|c|c|}
\hline \multirow{2}{*}{\multicolumn{2}{|c|}{ Period of fallow }} & \multicolumn{5}{|c|}{ State } & \multirow[t]{2}{*}{ Total } \\
\hline & & Adamawa & Benue & Kogi & Nasarawa & Taraba & \\
\hline \multirow[t]{2}{*}{$<1$ year } & Count & 93 & 97 & 44 & 108 & 95 & 437 \\
\hline & $\%$ within state & 31.7 & 33.3 & 30.3 & 44.8 & 39.6 & 36.1 \\
\hline \multirow[t]{2}{*}{$1-2$ years } & Count & 132 & 154 & 41 & 123 & 75 & 525 \\
\hline & $\%$ within state & 45.1 & 52.9 & 28.3 & 51.0 & 31.3 & 43.4 \\
\hline \multirow[t]{2}{*}{$3-4$ years } & Count & 37 & 29 & 54 & 7 & 42 & 169 \\
\hline & $\%$ within state & 12.6 & 10.0 & 37.2 & 2.9 & 17.5 & 14.0 \\
\hline \multirow[t]{2}{*}{ 5-6 years } & Count & 17 & 6 & 4 & 3 & 18 & 48 \\
\hline & $\%$ within state & 5.8 & 2.1 & 2.8 & 1.2 & 7.5 & 4.0 \\
\hline \multirow[t]{2}{*}{$7-8$ years } & Count & 9 & 2 & 2 & 0 & 3 & 16 \\
\hline & $\%$ within state & 3.1 & 0.7 & 1.4 & 0.0 & 1.3 & 1.3 \\
\hline \multirow[t]{2}{*}{$9-10$ years } & Count & 5 & 2 & 0 & 0 & 7 & 14 \\
\hline & $\%$ within state & 1.7 & 0.7 & 0.0 & 0.0 & 2.9 & 1.2 \\
\hline \multirow[t]{2}{*}{$>10$ years } & Count & 0 & 1 & 0 & 0 & 0 & 1 \\
\hline & $\%$ within state & 0.0 & 0.3 & 0.0 & 0.0 & 0.0 & 0.1 \\
\hline \multirow[t]{2}{*}{ Total } & Count & 293 & 291 & 145 & 241 & 240 & 1210 \\
\hline & $\%$ within state & 100.0 & 100.0 & 100.0 & 100.0 & 100.0 & 100.0 \\
\hline
\end{tabular}

Source: Fieldwork, 2017.

Particularly to be noted in this regard is the finding that $36.1 \%$ of respondents in the study reported annual cropping which does not permit any year of fallow. In fact cases of multicropping were observed in which farm plots were continuously planted with alternative crops in the course of a year. Multicropping, according to Boserup $(1965,1981)$, is the highest level of land use intensification known to farmers who are yet to adopt industrial methods of agricultural land use. It is an agro-ecological approach to intensification of agricultural land use and occurs only in situations of extreme land shortage in rural areas.

The scenario of increasing frequency of agricultural land use as seen in the area is better appreciated when weighed against the background reported in studies by Downes (1933), Briggs (1941) and Bohannan (1954) which indicated fallow periods of 15, 10 and seven years respectively in northern Tivland of present Benue State in the central part of the basin. The frequency has changed rather fast, shortening fallow periods in a manner that has eliminated forest regrowth and bushes to allow only 'weeds fallow' in many parts of the region. For rewarding arable farming activity to be sustained in the area under the context, farmers need to be encouraged to adopt safe industrial methods of intensification of land use such as use of organic fertiliser, cultivation of improved varieties of crops, conscious application of household wastes on farms and irrigation.

\section{Land use intensification on large scale farms}

Within the last 35 years there has been a growing trend towards large scale farms that are run along the path of industrial intensification of agricultural land use involving use of fertilisers, insecticides, improved varieties of crops, irrigation and processing of farm produce. This development has been necessitated by the need to fill food and raw material supply gap within the basin and in the nation that could not be filled by smallholder agriculture. Farm enterprises which have emerged in the wake of the new trend are characterised by non-export production, plot consolidation, single cereal crop cultivation and private ownership; and are managed on corporate principles. The new farms produce solely for the market. With this motive, they adopt all possible measures to increase and sustain maximum yield from the land. The farms are shown in Table 6. 
Table 6: Emerging large farms in the Benue basin

\begin{tabular}{|c|c|c|c|c|}
\hline Name of farm & State of location & Farming activity & Size (ha) & Products \\
\hline Sebore Farm & $\begin{array}{l}\text { Sebore, } \\
\text { Adamawa }\end{array}$ & $\begin{array}{l}\text { Livestock, } \\
\text { maize, tree } \\
\text { crops, fishery }\end{array}$ & 1,500 & $\begin{array}{l}\text { Maize, fruits, } \\
\text { date palm nuts, } \\
\text { milk, yoghourt, } \\
\text { cows. }\end{array}$ \\
\hline $\begin{array}{l}\text { Gidan Madara } \\
\text { Farm }\end{array}$ & Mubi, Adamawa & $\begin{array}{l}\text { Livestock, } \\
\text { pasture research }\end{array}$ & 746 & $\begin{array}{l}\text { Livestock } \\
\text { product }\end{array}$ \\
\hline $\begin{array}{l}\text { Mayo-Bani } \\
\text { Farm }\end{array}$ & $\begin{array}{l}\text { Mayo-Bani, } \\
\text { Adamawa }\end{array}$ & $\begin{array}{l}\text { Cropping } \\
\text { scheme research }\end{array}$ & 30 & $\begin{array}{l}\text { Cropping } \\
\text { innovations }\end{array}$ \\
\hline Green House & Jalingo, Taraba & $\begin{array}{l}\text { Vegetable } \\
\text { farming }\end{array}$ & 5 & $\begin{array}{l}\text { Tomatoes } \\
\text { vegetables }\end{array}$ \\
\hline Oracle Farms & $\begin{array}{l}\text { Gbajimba, } \\
\text { Benue }\end{array}$ & Rice, soyabeans & 300 & $\begin{array}{l}\text { Rice } \\
\text { soyabeans }\end{array}$ \\
\hline Olam Farms & $\begin{array}{l}\text { Rukubi, } \\
\text { Nasarawa }\end{array}$ & Rice production & 4,000 & Rice \\
\hline Oriya Farm & $\begin{array}{l}\text { Doma, } \\
\text { Nasarawa }\end{array}$ & $\begin{array}{l}\text { Sesame, maize } \\
\text { \& yam }\end{array}$ & 45 & $\begin{array}{l}\text { Beniseed, maize } \\
\& \text { yam }\end{array}$ \\
\hline Madu Farms & $\begin{array}{l}\text { Agwavou, } \\
\text { Nasarawa }\end{array}$ & $\begin{array}{l}\text { Sorghum, } \\
\text { cassava \& cattle }\end{array}$ & 25 & $\begin{array}{l}\text { Cows \& cassava } \\
\text { products }\end{array}$ \\
\hline
\end{tabular}

Source: Fieldwork, 2017

Field observation revealed evidence of use of scientific methods on the farms in form of mechanisation of operations, use of herbicides and insecticides as well as processing of farm produce to add value and elongate shelf life of commodities coming from the farms. In other words, the emerging large farms are truly commoditising food crops in the Benue basin. Plates 1-4 show some of the large farm scenes.

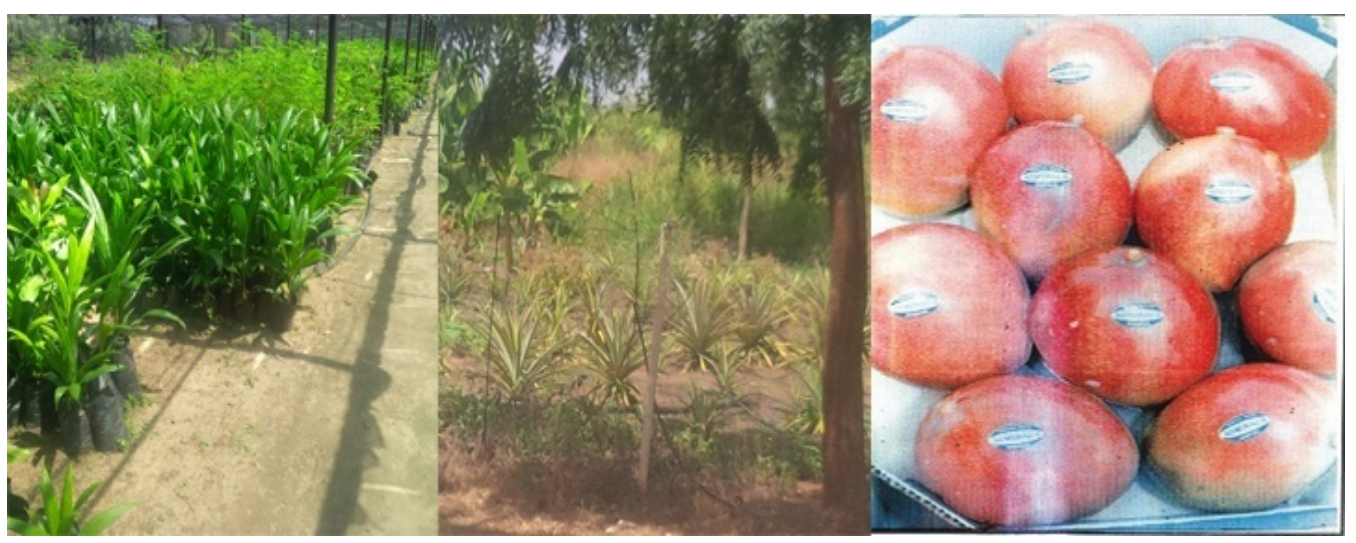

Plate 1: Maize \& pineapple section of Sebore Farms, Adamawa State 


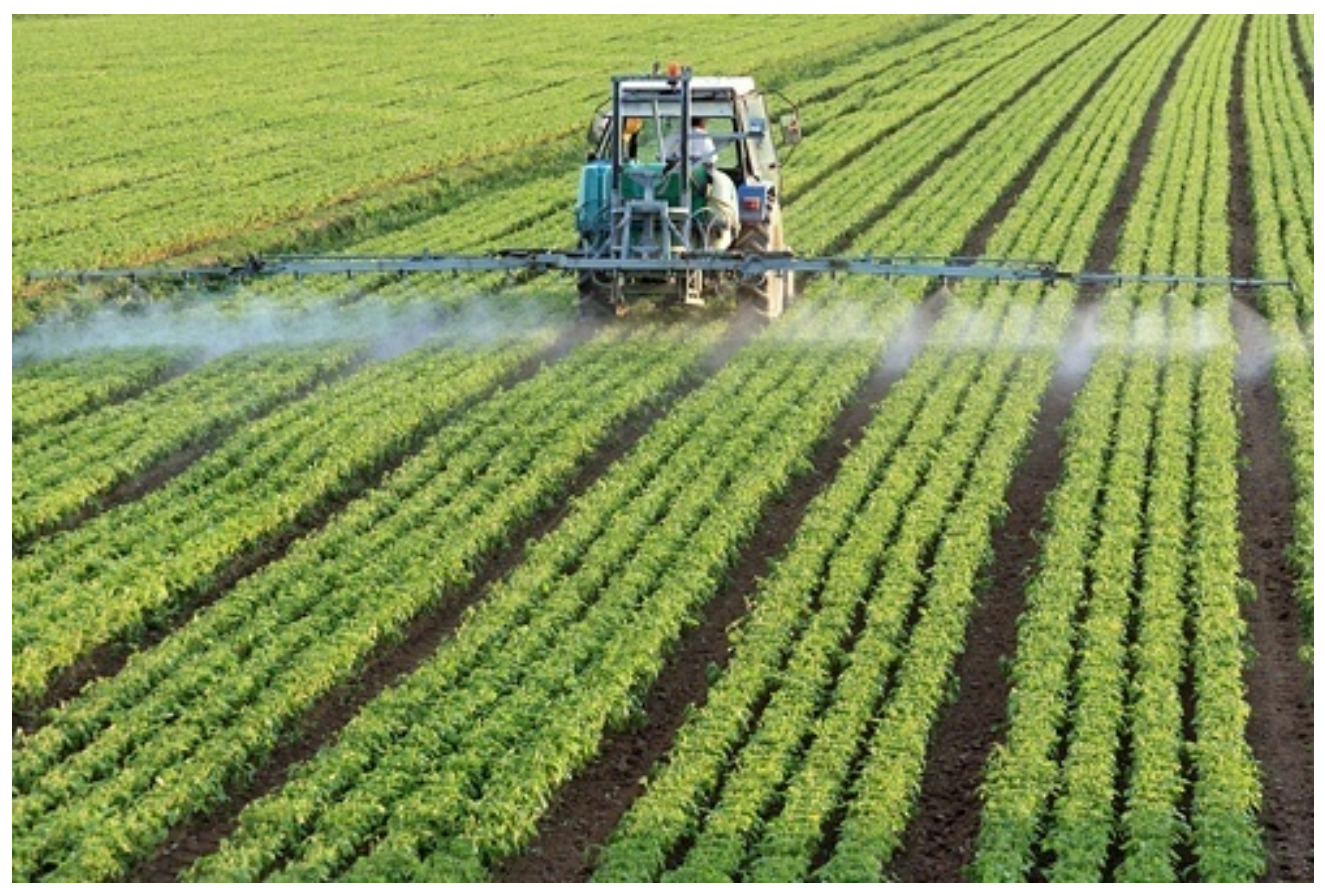

Plate 2: Olam rice farm at Rukubi, Nasarawa State

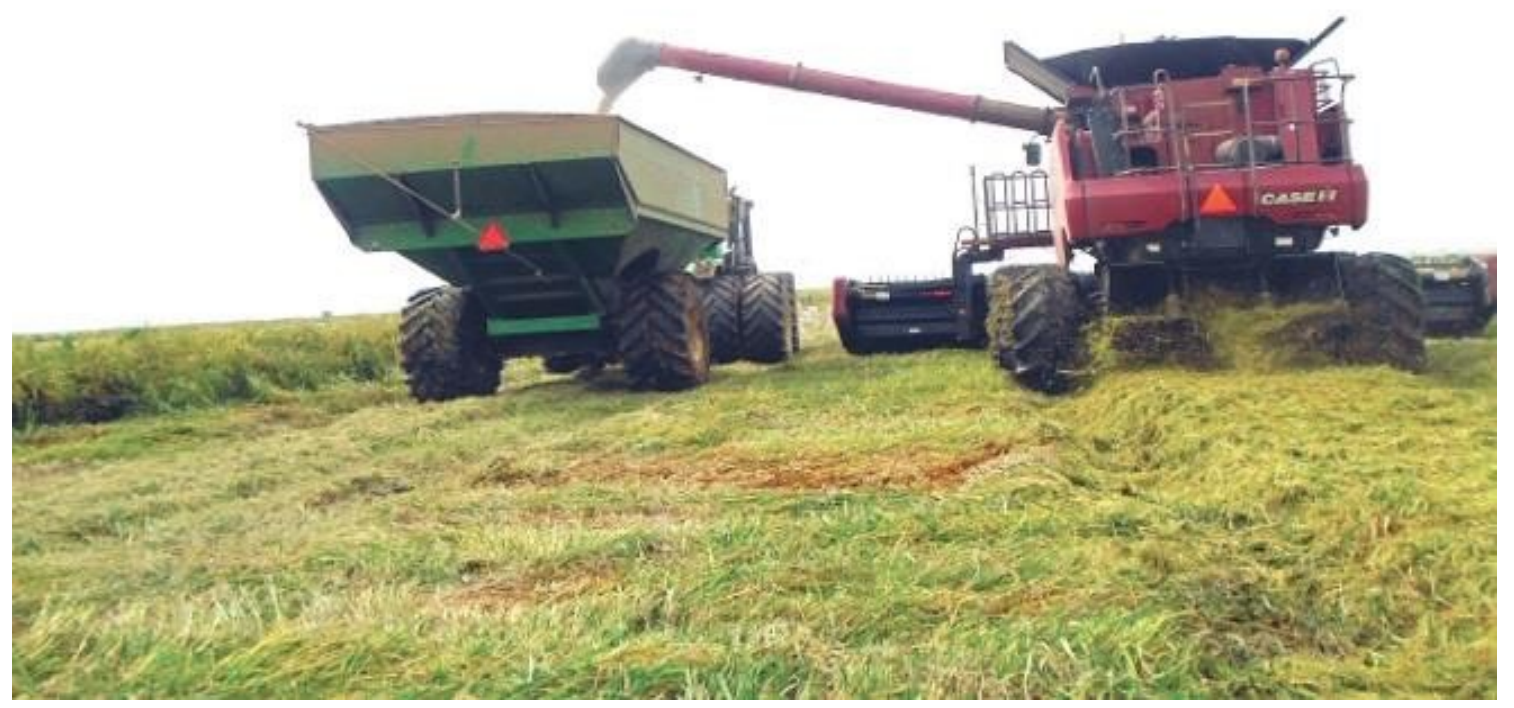

Plate 3: Mechanised harvesting of rice, Olam Farm at Rukubi, Nasarawa State 


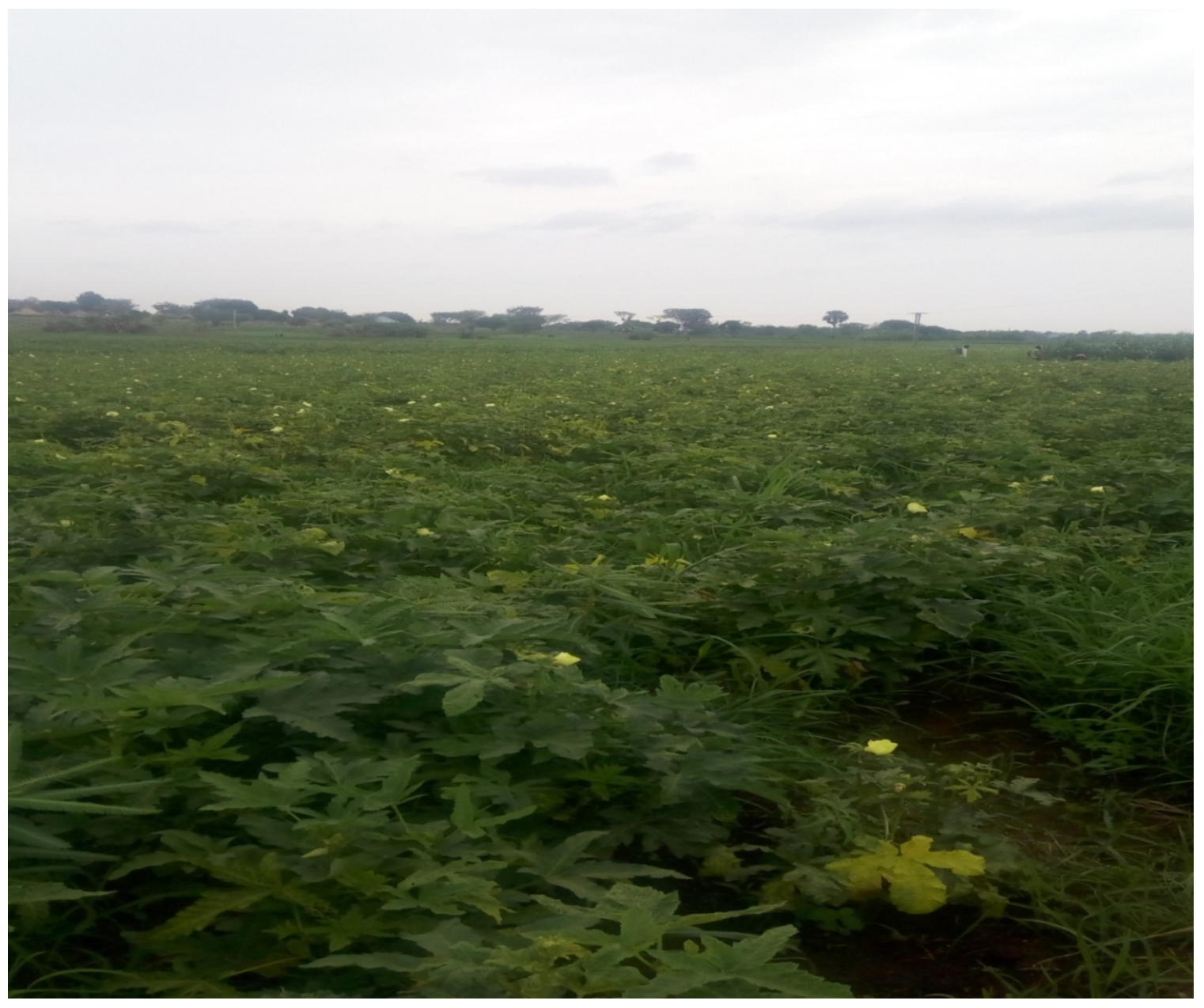

Plate 4: Vegetable Farm at Buruku, Benue State

Large scale farms are a recent phenomenon in the Benue basin, mainly within the last 35 years. Even vegetable farming which is traditionally known to be a small scale venture on scattered plots is tending towards concentration in the region. The Green House Vegetable Farm in Jalingo, Taraba State occupying five hectares of land represents the new thinking in this sector of intensive farming. No population other than urban population can offer threshold demand for such scale of vegetable production. The incidence of such farms in the Benue basin indicates the growing impact of urban growth on agriculture in the region.

\section{Main drivers of increasing agricultural land use intensity in the Benue basin}

Field investigation of farmers in the Benue basin revealed that farmers in the region are deliberately intensifying land use in reaction to new ecological and market environments so that they can viably sustain production for family and market demands. Their responses regarding reasons for employing various methods of land use intensification were unambiguously linked to these scenarios as presented in Table 7. 
Table 7: Major reasons for adopting intensive methods of land use in the Benue basin

\begin{tabular}{|c|c|c|c|c|c|c|c|}
\hline \multirow{2}{*}{\multicolumn{2}{|c|}{ Main reasons }} & \multicolumn{5}{|c|}{ State } & \multirow[t]{2}{*}{ Total } \\
\hline & & Adamawa & Benue & Kogi & Nasarawa & Taraba & \\
\hline Urban demand & $\begin{array}{l}\text { Count } \\
\% \quad \text { within } \\
\text { State }\end{array}$ & $\begin{array}{l}85 \\
41.5 \%\end{array}$ & $\begin{array}{l}104 \\
50.2 \%\end{array}$ & $\begin{array}{l}9 \\
9.3 \%\end{array}$ & $\begin{array}{l}27 \\
16.8 \%\end{array}$ & $\begin{array}{l}43 \\
29.1 \%\end{array}$ & $\begin{array}{l}268 \\
32.8 \%\end{array}$ \\
\hline Rural demand & $\begin{array}{l}\text { Count } \\
\% \quad \text { within } \\
\text { State }\end{array}$ & $\begin{array}{l}17 \\
8.3 \%\end{array}$ & $\begin{array}{l}25 \\
12.1 \%\end{array}$ & $\begin{array}{l}35 \\
36.1 \%\end{array}$ & $\begin{array}{l}38 \\
23.6 \%\end{array}$ & $\begin{array}{l}28 \\
18.9 \%\end{array}$ & $\begin{array}{l}143 \\
17.5 \%\end{array}$ \\
\hline $\begin{array}{l}\text { Processing } \\
\text { facilities }\end{array}$ & $\begin{array}{l}\text { Count } \\
\% \text { within } \\
\text { State }\end{array}$ & $\begin{array}{l}15 \\
7.3 \%\end{array}$ & $\begin{array}{l}6 \\
2.9 \%\end{array}$ & $\begin{array}{l}2 \\
2.1 \%\end{array}$ & $\begin{array}{l}18 \\
11.2 \%\end{array}$ & $\begin{array}{l}8 \\
5.4 \%\end{array}$ & $\begin{array}{l}49 \\
6.0 \%\end{array}$ \\
\hline $\begin{array}{l}\text { Changes in } \\
\text { soil, climate \& } \\
\text { pest }\end{array}$ & $\begin{array}{l}\text { Count } \\
\% \text { within } \\
\text { State }\end{array}$ & $\begin{array}{l}1 \\
0.5 \%\end{array}$ & $\begin{array}{l}22 \\
10.6 \%\end{array}$ & $\begin{array}{l}39 \\
40.2 \%\end{array}$ & $\begin{array}{l}33 \\
20.5 \%\end{array}$ & $\begin{array}{l}30 \\
20.3 \%\end{array}$ & $\begin{array}{l}125 \\
15.3 \%\end{array}$ \\
\hline $\begin{array}{l}\text { Urban \& rural } \\
\text { demand }\end{array}$ & $\begin{array}{l}\text { Count } \\
\% \text { within } \\
\text { State }\end{array}$ & $\begin{array}{l}24 \\
11.7 \%\end{array}$ & $\begin{array}{l}7 \\
3.4 \%\end{array}$ & $\begin{array}{l}9 \\
9.3 \%\end{array}$ & $\begin{array}{l}32 \\
19.9 \%\end{array}$ & $\begin{array}{l}20 \\
13.5 \%\end{array}$ & $\begin{array}{l}92 \\
11.2 \%\end{array}$ \\
\hline $\begin{array}{l}\text { Urban demand } \\
\& \text { processing } \\
\text { facilities }\end{array}$ & $\begin{array}{l}\text { Count } \\
\% \text { within } \\
\text { State }\end{array}$ & $\begin{array}{l}19 \\
9.3 \%\end{array}$ & $\begin{array}{l}4 \\
1.9 \%\end{array}$ & $\begin{array}{l}0 \\
0.0 \%\end{array}$ & $\begin{array}{l}7 \\
4.3 \%\end{array}$ & $\begin{array}{l}13 \\
8.8 \%\end{array}$ & $\begin{array}{l}43 \\
5.3 \%\end{array}$ \\
\hline $\begin{array}{l}\text { Demand \& } \\
\text { changes in } \\
\text { soil, climate, } \\
\text { pest }\end{array}$ & $\begin{array}{l}\text { Count } \\
\% \text { within } \\
\text { State }\end{array}$ & $\begin{array}{l}44 \\
21.5 \%\end{array}$ & $\begin{array}{l}7 \\
3.4 \%\end{array}$ & $\begin{array}{l}3 \\
3.1 \%\end{array}$ & $\begin{array}{l}6 \\
3.7 \%\end{array}$ & $\begin{array}{l}6 \\
4.1 \%\end{array}$ & $\begin{array}{l}66 \\
8.1 \%\end{array}$ \\
\hline All the above & $\begin{array}{l}\text { Count } \\
\% \text { within } \\
\text { State }\end{array}$ & $\begin{array}{l}0 \\
0.0 \%\end{array}$ & $\begin{array}{l}32 \\
15.5 \%\end{array}$ & $\begin{array}{l}0 \\
0.0 \%\end{array}$ & $\begin{array}{l}0 \\
0.0 \%\end{array}$ & $\begin{array}{l}0 \\
0.0 \%\end{array}$ & $\begin{array}{l}32 \\
3.9 \%\end{array}$ \\
\hline Total & $\begin{array}{l}\text { Count } \\
\% \text { within } \\
\text { State }\end{array}$ & $\begin{array}{l}205 \\
100.0 \%\end{array}$ & $\begin{array}{l}207 \\
100.0\end{array}$ & $\begin{array}{l}97 \\
100.0\end{array}$ & $\begin{array}{l}161 \\
100.0\end{array}$ & $\begin{array}{l}148 \\
100.0\end{array}$ & $\begin{array}{l}818 \\
100.0\end{array}$ \\
\hline
\end{tabular}

Source: Field work, 2017.

Changes in the level of intensity of agricultural land use usually come at capital and labour costs to farmers adopting them, and therefore can only come if there are compelling reasons to necessitate them. Emerging intensification of agricultural land use in the Benue basin illustrates this scenario as it is closely associated with compelling ecological circumstances in the area. Farming generally, but the one spurred by pecuniary motive especially, is sensitive to shifts in ecological environment and market expansion, striving constantly to fit into emerging ecological and new market scenarios in an area. For sustainability of farming in a crowding world is guaranteed only through the process of land use intensification.

The increased urban and rural demands for farm produce which majority of the respondents mentioned as major reason for intensifying land use owe primarily to increased population in the fast growing towns and villages in the region and to rising consumption level. These developments have eliminated the colonial dichotomy between cash crops and staple food crops. Population growth and rapid urbanisation in the basin since 1900 have provided insatiable demand for virtually all kinds of farm produce which encourages farmers to increase production using every means available.

Similarly, respondents explained their adoption of intensive practices by changes in soil fertility, climate and pest menace. Reduced soil fertility in particular has necessitated application of artificial fertilisers; climate variability resulting to unpredictable time for onset and cessation of rainfall has imposed adoption of new varieties of crops that can tolerate the condition better. Increased pest invasion in the area has also forced farmers to substitute one variety of crop with another to sustain yield. Augmenting the impact of ecological factors has been appearance of processing facilities such as rice mills, cassava processing plants, vegetable 
oil mills which have encouraged farmers to intensify farming activities through reduction of waste, value addition and longer shelf life of farm produce.

Of all the causes of agricultural land use intensification in the Benue basin, the combined desire to produce surplus for subsistence and for sale constitute the major driver of the process. It was cited by $78.1 \%$ of respondents as a major motivation for intensifying land use. The prevalence of this motive among farmers in the region is shown on Figure 6.

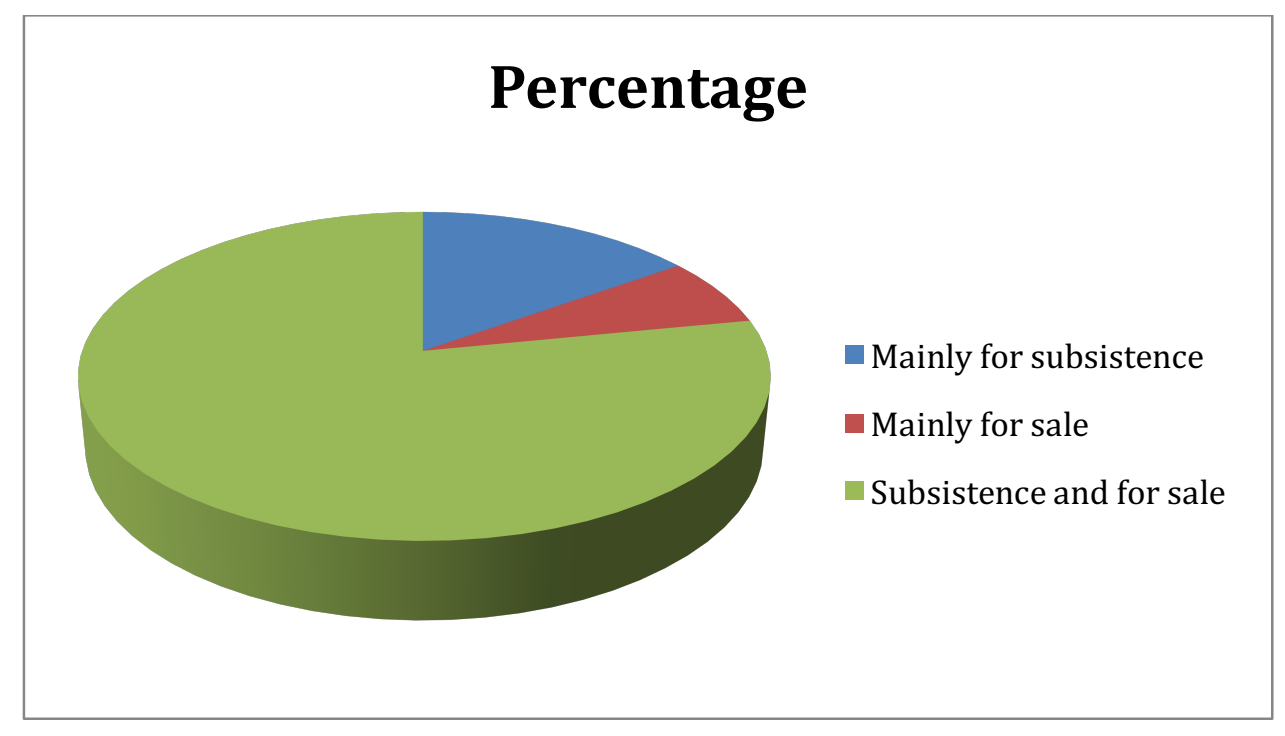

Figure 6: Main motives for producing crops by rural farmers Source: Fieldwork, 2017.

This motive scored consistently high across the five states of the basin. It should be noted that the market in reference is domestic market where buyers and producers share common tastes. It remains a challenge that the region has access to only local and national segments of the global value chain, and therefore does not reap maximum benefits from farming activity.

\section{DISCUSSION OF FINDINGS}

The study investigated intensification of arable land use in the Benue basin under three major objectives. Level of intensification of land use in the region was found to be varied in some specific aspects. It was high in terms of input application as all respondents reported deliberate use of one form of input or another, just as it was high in terms of frequency of farm plot use for which 79.5\% of respondents allowed fallow periods of only two years and below. Level of intensification involving high yielding crop varieties however was low as majority of farmers reported cultivation of traditional varieties of crop.

From the findings, it is clear that the region's farming systems represent many syntheses: agroecological methods mixed with industrial methods of farming, subsistence with market production, seasonal production with year round production, small scale with large scale farming, all going on side by side in the basin. These mixtures indicate farming systems in transition from traditional agriculture to modern agriculture and from subsistence agriculture to commodity production.

In spite of the deliberate to effort to intensify land use, agriculture in the region is virtually domestic in orientation. One attribute of agriculture in the basin that has constrained deeper interaction with the global market, and has therefore reduced the region's capacity to abstract 
greater benefits from external sources is the absence of what Thanh and Tacoli (2010) call 'high-value farm produce' with global appeal. The traditional food staples which find demand only within the country have excluded the region's farm produce from the global value chain and its associated benefits. The global crave for fresh fruits, especially in the global north, which the region possesses ecological capability to produce, for example, is yet to stimulate aspiration to produce for world market. Mangoes and citrus currently produced in parts of the region do not meet the standards of the global market in terms of size, shape, colour, cultivation methods, and environmental impact and storage conditions. Interaction with farmers during field investigation revealed that farmers in the region do not think about these quality aspects of what they produce. As Fold and Tacoli (2010) note, meeting these standards requires corporate capital, and it is well beyond the reach of smallholder farmers who dominate the area.

They need deliberate intervention through extension services to expose them to new methods of cultivation which will enable them produce and store to standards. Sebore Farms organises training workshops and seminars for farmers on the best practices in agriculture and farming techniques. But such services are practically not for smallholder farmers that dominate the region. They are, to their level, still too theoretical and not adequately down-to-earth to make full impact on them. Smallholder farmers learn better 'by the eye' than 'by the ear.'

There is therefore every need to research in agricultural systems in the Benue basin to understand the direction and magnitude of changes in the systems. The region doubtlessly is still characterised by smallholder production, but farmers have shown clear disposition towards commoditisation and innovation adoption to develop agriculture in the area.

The import of the findings is that farmers in the area have accepted the philosophy and principles of agricultural productivism, and are prepared to adopt innovations in farming. The limited innovations which are disseminated by state institutions like the Upper Benue River Basin and Lower Benue River Basin development authorities, Benue Agricultural and Rural Development Agency (BNARDA) are well accepted by farmers in the area. Farmers need more. Research institutions and government can exploit the current predisposition towards innovation adoption to develop agriculture in the area.

\section{CONCLUSION}

This study has revealed one character of farmers in the Benue basin which can be exploited for rapid improvement of agriculture and agrarian situation in the region, the unmistakable disposition toward adoption of agricultural innovations. They have demonstrated this propensity by acceptance of limited innovations in inputs, improved crop varieties, management of declining fallow periods and increasing commercialisation of production even in the absence of a formal system of extension services. The dynamism exhibited through the numerous changes farmers in the region introduce on their farms is in attempt to respond to demand offered by the growing urban centres for food and agricultural raw materials.

We need to understand changes in the region's agricultural systems in order to know which aspects of the change to encourage, discourage or redirect towards better ends. This is especially important in a region that is fast urbanising and needs a vibrant rural economy to maintain a functional balance between towns and villages. Clearly urbanisation in the area, in particular and in the country as a whole, is instrumental to increasing intensity of agricultural land use. The link should be encouraged and maintained. 


\section{Acknowledgements}

This study was funded by the Department for International Development (DFID), a United Kingdom government department responsible for administering overseas development aid. It was part of the wider Rural-urban linkages within the Benue basin in Central Nigeria. We are grateful to the department for the fund. We are also grateful to all our field assistants, community leaders and government officials in the five states covered by the study for their assistance and cooperation.

\section{Disclosure statement}

No conflict of interest was reported by the authors of the study.

\section{Supplementary data}

Data in Table 2 was adapted from population records of the National Population Commission of Nigeria, data in Table 3 was adapted from Iorliam S.I. et al (2017), photographs of activities on modern farms came from Nassoft IT consult (2013) \& http://www.linknaija.com/2016/07/governorortom-visits-his-oracle-farm.html.

\section{References}

Ayih, S.O. (2003). Nasarawa State: Past and Present. Abuja: Umbrella Books. Boserup, E. (1965). The Conditions of Agricultural Growth: The Economies of Agrarian Change under Population Pressure. London: Longman.

Boserup, E. (1981). Population and Technological Change: A Study of Term Trends. Chicago: University of Chicago Press.

Dornbush, M.E. \& von Haden, A.C. (2017). Intensified agroecosystems and their effects on soil biodiversity and soil functions. In Soil Health and Intensification of Agroecosystems, 2017. Sciencedirect.com/tropics/earth-andplanetary-sciences/agricultural-intensification. Federal Republic of Nigeria, Official Gazette, No. 4, Vol. 94.

Fold, N. \& Tacoli, C. (2010). Agricultural frontier settlements: markets, livelihood diversification and small town development. In Jytte Agergaard, Neils Fold \& Katherine V. Gough (eds), Rural-Urban Dynamics: Livelihoods, mobility and marketsin Africa and Asian frontiers, pp. 90-98.

Forrest, T.G. (1986). Agricultural policies in Nigeria 1900-1980; Department of Political Science Seminar, Vol. 2; Ahmadu Bello University, Zaria, Nigeria.

Freeman, H.A. (1994). Population pressure, land use and the productivity of agricultural systems in West African savannah. In Breth S.A. (ed), Issues in African Rural development 2. Arlington: Winrock International Institute for Agriculture, pp. 103-113.

Grigg, D. (1979). Ester Boserup's theory of agrarian change: a critical review. Progress inHuman Geography 3 (1), p. 64-84.

Iorliam, S.I; Alaci, D.; Atser, J; Kwaghsende, F; Dam, P. D; Anule, P; Mngutyo, I; Ajene, A; Adaaku, E. \& Gyuse, T. (2017). Urban growth and emerging urban systems in the Benue basin. DFID Research Validation Workshop, held at Benue Hotels, Makurdi, 23rd-24th August, 2017.

Kodithuwakku, S.S. \& Rosa, P. (2002). The entrepreneurial process and economic success in a constrained environment. Journal of Business Venturing, 17 (5), pp. 431-65.

Kwa, A. (2001). Agriculture in developing countries: which way forward? Occasional paper On Global South, T.R.A.D.E. occasional papers 4.

Moss, R.P. (1969). An ecological approach to the study of soils and land in the forest zone ofNigeria. In Thomas, M.F.\& Whittington, G.W. (eds), Environment and Land Use in Africa. London: Methuen, pp. 385-403.

National Population Commission (1998). 1991 Population Census of the Federal Republic of Nigeria: Analytical Report at the National Level. Abuja: NPC

National Population Commission (NPC) \& ICF International (2014). Nigeria Demographic Health Survey 2013. Abuja, Nigeria, \& Rockville, Maryland, USA: NPC ICF International.

Ortserga, D.S. (2010). Emerging patterns of agricultural land use in Ute Districts of Vandeikya Local Government Area of Benue State, Nigeria. A PhD thesis submitted to Postgraduate School, Benue State University, Makurdi. 
Pellegrini, P. \& Fernandez, R. (2018). Crop intensification, land use and on-farm energy-use efficiency during the worldwide spread of the green revolution. PNAS March, 2018, 115 (10) 2335-2340; ttps://doi.org/10.1073/pnas.1717072115

Personal communication with Tukwa, March 17, 2009.

Stone, G.D. (2001). Agricultural change theory. Human Ecology, 30, pp. 329-33.

Thanh, H.X. \& Tacoli, C. (2010). Transforming livelihood and settlements: fruit productionand urbanisation in Vietnam's Mekong Delta. In Jytte Agergaard, Neils Fold \& Katherine V. Gough (eds), Rural-Urban Dynamics: Livelihoods, mobility and marketsin Africa and Asian frontiers, pp. 74-89. Abingdon: Routledge.

Woods, M. (2011). Rural, Abingdon: Routledge. Scarborough, V.L. (2012). Land use and intensification. In Nichols, D.L. (ed), The Oxford Handbook of Mesoamerican Archaeology. Online publication, DOI:

10.1093/oxfordhb/9780195390933.013.0038

Strahler, A.H. \& A.N. Strahler (1994). Introducing Physical Geography. New York: JohnWiley \& Sons. 